Article

\title{
Human Rights of Children in the Context of Migration Processes. Innovative Efforts for Integrating Regional Human Rights Standards in the Americas
}

\author{
Alejandro Fuentes ${ }^{1, *}$ and Marina Vannelli ${ }^{2, *(1)}$ \\ 1 Raoul Wallenberg Institute of Human Rights and Humanitarian Law (RWI), P.O. Box 1155, \\ SE-221 05 Lund, Sweden \\ 2 Department of Law, Umeå University, 90187 Umeå, Sweden \\ * Correspondence: alejandro.fuentes@rwi.lu.se (A.F.); marina.vannelli@umu.se (M.V.)
}

Received: 24 June 2019; Accepted: 15 October 2019; Published: 22 November 2019

\begin{abstract}
This paper proposes a critical analysis of the innovative jurisprudential approaches taken by the Inter-American Court of Human Rights in integrating the content and scope of protection of the human rights of children, in the context of migration processes. How might one provide an effective protection to unaccompanied children that enter irregularly into the territory of a given country, when the safeguards guaranteed at the national level are elusive or inefficient? By focusing on the pioneering jurisprudence developed by the Inter-American Court of Human Rights in recent years, this paper intends to unveil how a systemic integration of children's rights, under the light of the current international law developments, could provide an effective protection for the rights of children in the context of migration processes. In fact, as a result of an evolutive, dynamic and effective interpretation, the regional tribunal has expanded the scope of protection of the American Convention on Human Rights, by taking into consideration and making known, references to instruments and provisions enshrined within the corpus juris of international human rights law, such as the UN Convention of the Rights of the Child, and-consequently-improving the level of protection of millions of children in the Americas.
\end{abstract}

Keywords: human rights; Inter-American Court of Human Rights; judicial interpretation; child rights; best interest principle; migration; systemic integration; international law; corpus juris

\section{Introduction}

The critical situation of migrant children in the Americas has deteriorated dramatically in recent years, to the point where children are nowadays affected by continuous violations of many of their fundamental rights; including - among others — the right to life, education, family life, health, access to justice, and the right to be heard. ${ }^{1}$ In this context, the migration of children assumes a regional dimension that goes beyond the different national realities, equally affecting children in their countries of origin, transit and destination (CGRS 2015, p. 8).

This phenomenon has generated an increasing amount of children seeking asylum in the Americas. ${ }^{2}$ In addition, it has situated child migrants in a particular situation of vulnerability, which has not yet

1 For an overview of the situation of migrant children in the Americas, see-among others-Inter-American Commission of Human Rights (IACHR 2015a, 2015b).

2 See (UN High Commissioner for Refugees (UNHCR) 2014). 
been fully and effectively assessed at national or regional levels in the Americas. ${ }^{3}$ The lack of national responses has paved the way for the emergence and development of a regional jurisprudence by the Inter-American Court of Human Rights (IACrtHR, the court or the Inter-American Court). ${ }^{4}$ As a result, the regional tribunal has played a fundamental role in the recognition of the rights of children seeking asylum in the Americas, by means of developing their rights under the light of the systemic integration of International Human Rights Law (IHRL). ${ }^{5}$

In other words, by applying an evolutive, dynamic and effective interpretation of the American Convention on Human Rights (ACHR, the convention or the American Convention), ${ }^{6}$ the court has interpreted its provisions under the light of all other universal or regional instruments that would be legally relevant and substantially connected with a specific case, in order to provide the most effective protection to migrant children in situation of vulnerability in the Americas. This innovative method of interpretation has not only expanded the scope of protection of children's rights, as recognized within the ACHR, but also generated a new legal narrative based on the 'humanization' of international law (Cançado Trindade 2013), and focused on children's needs and their situation of vulnerability as, for instance, the unaccompanied child (pro-homine principle). ${ }^{7}$

In fact, the regional tribunal has interpreted migration norms as an integral part of the human rights regime; that is, as a body of norms that not only contains provisions that directly address and provide entitlements to individuals but also that it has contributed to the further development and 'humanization' of the international human rights corpus juris for the protection of children's rights. In other words, the IACrtHR has developed a de-fragmentized and integrative approach toward IHRL, making - for instance - explicit references to various provisions of the UN Convention on the Rights of the Child (CRC) while examining the content and scope of Article $19 \mathrm{ACHR},{ }^{8}$ aiming at enhancing the level of protection of millions of migrant children in the Americas and expanding states' positive obligations in relation to them.

Hence, this paper proposes a critical analysis of the jurisprudence developed by the Inter-American Court, focusing in particular, on the method of interpretation used by this regional tribunal that paved the way for the systemic integration of children's rights under international law. In addition, special emphasis is given to the manner in which the court has interpreted and further developed the corpus juris for the effective protection and concrete implementation of children's rights.

\section{Interpretation and Integration of IHRL in the Jurisprudence of the Inter-American Court}

The Inter-American Court applies in its interpretation of the American Convention, both the traditional or general methods of interpretation in international law and specific human rights-related rules of interpretation, which have been developed throughout the case law of the regional tribunal (Fuentes 2016).

As traditional methods of interpretation based on international law, the court applies general and supplementary rules of interpretation, in accordance with the provisions enshrined in Articles $31^{9}$ and

3 Ibid. See also (IACHR 2010, 2013a).

4 The Inter-American Court of Human Rights was created on 18 July 1978 by the entering into force of the American Convention on Human Rights (1969), as an autonomous judicial institution with the purpose of the interpretation and application of the American Convention.

5 E.g., Pacheco Tineo Family v. Plurinational State of Bolivia, 25 November 2013, IACrtHR, Preliminary Objections, Merits, Reparations and Costs, Series C No. 272.

6 The American Convention on Human Rights was adopted at the Inter-American Specialized Conference on Human Rights, San José, Costa Rica, 22 November 1969.

7 See Rights and Guarantees of Children in the Context of Migration and/or in Need of International Protection, 19 August 2014, IACrtHR, Advisory Opinion OC-21/14, Series A No. 21.

8 Article 19 ACHR (rights of the child) states that: "Every minor child has the right to the measures of protection required by his condition as a minor on the part of his family, society, and the state."

9 Article 31 VCLT states-in its first paragraph—-that "[a] treaty shall be interpreted in good faith in accordance with the ordinary meaning to be given to the terms of the treaty in their context and in the light of its object and purpose." 
$32^{10}$ of the Vienna Convention on the Law of Treaties (Vienna Convention or VCLT). ${ }^{11}$ Hence, the first guidance in the interpretation of the American Convention is-in light of Article 31 VCLT-its own object and purpose, which in the case of the ACHR-as a human rights treaty-is "the protection of the fundamental rights of the human being." ${ }^{\prime 2}$ Moreover, in the understanding of the IACrtHR, focusing on the object and purpose of the convention "respects the principle of the primacy of the text; that is, the application of the objective criteria of interpretation."13

Additionally, as indicated by the constant jurisprudence of the IACrtHR, it is important to highlight that the terms of an international human rights treaty have an autonomous and independent meaning, ${ }^{14}$ whose content is informed not only by the object and purpose of the same instrument, but also "interpreted by reference to their normative environment" in which the convention is integrated (Koskenniemi 2006, p. 209). Consequently, the scope of protection of conventional rights cannot be limited neither reduced in their interpretation by the existence of different legal definitions or notions within the domestic legal systems of state parties. To put it clear, the scope of protection of conventional rights refers to autonomous notions and institutions that are not conditioned neither limited by national legal systems.

Furthermore, together with the above-mentioned general method of interpretation, it is important to notice that the court also applies supplementary means of interpretation-as enshrined in Article 32 VCLT-in a subsidiary manner. ${ }^{15}$ For instance, in the views of the IACrtHR, the interpreter could make references to the preparatory work of a treaty in those cases in which is needed "to confirm the meaning resulting from that interpretation or when it leaves an ambiguous or obscure meaning, or leads to a result which is manifestly absurd or unreasonable."16 In this context, it is relevant to bear in mind that the supplementary means of interpretation cannot be used in a way that would considerably contravene the object and purpose of the convention. In fact, the interpreter should keep in mind that the inherent purpose of all treaties "is to be effective,"17 which in the case of human rights treaties means that their interpretation should be guided by the teleological purpose of delivering the effective protection of the human rights of individuals, together with "the creation of a legal order in which states assume obligations [...] towards the individuals subject to their jurisdiction."18 Therefore, the interpretation of the ACHR has to be done "in such a way that the system for the protection of human rights has all its appropriate effects (effet utile)."19 Based on this hermeneutical approach, the rights enshrined in the American Convention must not be interpreted in a sense that would reduce, restrict or limit their scope of protection in a way that could-consequently-substantially affect the object and purpose of this regional human rights treaty. ${ }^{20}$

10 Article 32 VCLT recognizes the possibility to recourse to supplementary means of interpretation, such as "the preparatory work of the treaty and the circumstances of its conclusion."

11 The Vienna Convention on the Law of Treaties was adopted on 23 May 1969 and entered into force on 27 January 1980.

12 Rights and Guarantees of Children, supra note 7, para. 31.

13 Restrictions to the Death Penalty (Arts. 4.2 and 4.4 American Convention on Human Rights), 8 September 1983, IACrtHR, Advisory Opinion OC-3/83, Series A No. 3, para. 50.

14 Case of the Mayagna (Sumo) Awas Tingni Community v. Nicaragua, 31 August 2001, IACrtHR, Merits, Reparations and Costs, Series C No. 79, para. 146.

15 See Case of González et al. ("Cotton field") v. Mexico, 16 November 2009, IACrtHR, Preliminary Objection, Merits, Reparations and Costs, Series C No. 205, para. 68.

16 Restrictions to the Death Penalty (Arts. 4.2 and 4.4 American Convention on Human Rights), supra note 13, para. 49.

17 Case of González et al. ("Cotton field"), supra note 15, para. 65.

18 Ibid, para. 62.

19 The Right to Information on Consular Assistance in the Framework of Guarantees for Due Legal Process, 1 October 1999, IACrtHR, Advisory Opinion OC-16/99, Series A No. 16, para. 58.

20 According to the court, "[T]he efficacy of the mechanism of international protection, must be interpreted and applied in such a way that the guarantee that it establishes is truly practical and effective, given the special nature of human rights treaties." Case of the Constitutional Court v. Peru, 24 September 1999, IACrtHR, Competence, Series C No. 55, para. 36. 
The above interpretation is reinforced by the provisions enshrined in Article 29 ACHR, ${ }^{21}$ which delineate the so-called principle of a non-restrictive interpretation (Comune and Luterstein 2012; Lixinski 2010). In fact, this provision precludes any restrictive interpretation of the rights and freedoms recognized in the convention through domestic legislation or other conventional obligations assumed by states Parties of the ACHR. ${ }^{22}$

In addition to this non-restrictive hermeneutical approach, the regional tribunal has further developed the conventional mandate to guarantee an effective protection of fundamental rights, by means of introducing a contextual, historical and evolutive interpretation of those rights. That is, an interpretation that could take into consideration all circumstances and contextual factors of the specific case under analysis. ${ }^{23}$ To put it differently, if the interpretation does not take into consideration the evolution of the social institutions, legal systems and socio-cultural transformations that continually occur in our societies, it would be unable to provide an effective protection of the fundamental rights at stake in a given case. In fact, "human rights treaties are living instruments, the interpretation of which must evolve with the times and current living conditions." ${ }^{24}$ Based on this consideration, the Inter-American Court has clearly stated in its constant jurisprudence that in matters of interpretation, it "must adopt the proper approach to consider [the scope of protection of a given right] in the context of the evolution of the fundamental rights of the human person in contemporary international law." 25

\subsection{Systemic Integration of the Corpus Juris of IHRL}

As concluded above, the evolutive interpretation of the American Convention imposes the obligation to interpret the extension and scope of protection of conventional rights under the "present-day conditions," ${ }^{26}$ that is, paying due attention to the societal context in which the case has emerged. Therefore, in addition to the evolution that takes place in society, the interpreter needs to situate that interpretation in the context of the evolution of the legal system of reference or to whichever the American Convention is part of.

In other words, in order to interpret the extension of the scope of protection of a given right under the "current present day conditions," the interpreter must also consider all other instruments and agreements directly related to the American Convention (Article 31(2)(a)(b) VCLT), together with "any relevant rules of international law applicable in the relations between the parties" (Article 31(3)(c) $\mathrm{VCLT}$ ). These provisions introduced the principle of systemic integration of international law (Mc Lachlan 2005; Koskenniemi 2006; Rachovitsa 2017) by which "norms should be interpreted as part of a whole, the meaning and scope of which must be defined based on the legal system to which they belong." 27 To put it clearly, "The interpretation of a treaty should take into account not only the agreements and instruments formally related to it (Article 31(2) of the Vienna Convention), but also its

21 Article 29 ACHR (Restrictions Regarding Interpretation) reads as follows: "No provision of this Convention shall be interpreted as: (a) permitting any state party, group, or person to suppress the enjoyment or exercise of the rights and freedoms recognized in this convention or to restrict them to a greater extent than is provided for herein; (b) restricting the enjoyment or exercise of any right or freedom recognized by virtue of the laws of any state party or by virtue of another convention to which one of the said states is a party; (c) precluding other rights or guarantees that are inherent in the human personality or derived from representative democracy as a form of government; (d) ... "

22 In this sense, the court has stressed that: "Any interpretation of the Convention that [ ... ] would imply suppression of the exercise of the rights and freedoms recognized in the Convention, would be contrary to its object and purpose as a human rights treaty." Ivcher Bronstein v. Peru, 24 September 1999, IACrtHR, Competence, Series C No. 54, para. 41.

23 See Case of Yatama v. Nicaragua, 23 June 2005, IACrtHR, Concurring Opinion of Judge Sergio Garcia-Ramirez, para. 7.

24 The Right to Information on Consular Assistance, supra note 19, para. 114. See also Case of Artavia Murillo et al. ("In vitro fertilization") v. Costa Rica, 28 November 2012, IACrtHR, Preliminary Objections, Merits, Reparations and Costs, Series C No. 257, para. 245.

25 The Right to Information on Consular Assistance, supra note 19, para. 115.

26 Ibid, para. 114. See also Case of the Gomez Paquiyauri Brothers v. Peru, 8 July 2004, IACrtHR, Merits, Reparations and Costs, Series A No. 18, para. 165.

27 González et al ("Cotton field"), supra note 15, para. 43. 
context (Article 31(3)), ${ }^{\prime 28}$ which in the case of the American Convention-as a human rights treaty-is the "international human rights law." 29

Therefore, when applying a systemic interpretation, the regional tribunal does not limit itself to the provisions contained within the American Convention (e.g., by exploring the interconnection or interrelation between relevant rights), but would rather contemplate all other regional or universal human rights instruments that could assist and provide guidelines on its hermeneutical efforts to determine the specific level of protection afforded by the ACHR in a given case. ${ }^{30}$ The relevance of the systemic interpretation in international law has been highlighted by the International Court of Justice (ICJ) since it celebrated obiter dictum in the Namibia case, when sentenced that "an international instrument has to be interpreted and applied within the framework of the entire legal system prevailing at the time of the interpretation." 31

However, it is noteworthy to mention that the principle of a systemic interpretation or integration of international human rights law does not provide the court with the possibility to resolve a specific case through the direct application of a different instrument than the ACHR. ${ }^{32}$ Only violations to rights enshrined in the ACHR, or within other treaties that explicitly or implicitly recognize the competence of the court, will open the jurisdiction of the regional tribunal. ${ }^{33}$ Accordingly, through the implementation of this principle, the court has been able to make references to other relevant instruments-part of the corpus juris of international human rights law-which provisions are capable to pave the way for the development of an evolutive, contextual and non-restrictive understanding of the rights recognized within the American Convention. ${ }^{34}$

In short, the court does nothing but apply the American Convention, interpreted under the light of the corpus juris of international human rights law. As mentioned by the IACrtHR,

"The corpus juris of international human rights law comprises a set of international instruments of varied content and juridical effects (treaties, conventions, resolutions and declarations). Its dynamic evolution has had a positive impact on international law in affirming and building up the latter's faculty for regulating relations between states and the human beings within their respective jurisdictions. This court, therefore, must adopt the proper approach to consider this question in the context of the evolution of the fundamental rights of the human person in contemporary international law." 35

The importance of the corpus juris has been stressed by the former president of the Inter-American Court, Judge Cançado Trindade (currently serving as a judge at the ICJ), by manifesting that states are "bound by the corpus juris of the international protection of human rights, which protects every human person erga omnes, independently of her statute of citizenship, or of migration, or any other condition or circumstance." ${ }^{36}$

28 The Right to Information on Consular Assistance, supra note 19, para. 113.

29 Artavia Murillo, supra note 24, para. 191.

30 In this sense, the court has declared that it could "address the interpretation of a treaty provided it is directly related to the protection of human rights in a member state of the Inter-American System," even if that instrument does not belong to the same regional system of protection. Kitchwa Indigenous People of Sarayaku v. Ecuador, 27 June 2012, IACrtHR, Merits and Reparations, Series C No. 245, para. 161.

31 Legal Consequences for States of the Continued Presence of South Africa in Namibia (South West Africa), Notwithstanding Security Council Resolution 276 (1970), 21 June 1971, ICJ, Advisory Opinion, I.C.J. Reports 1971, p. 19.

32 In connection with the direct inapplicability of international instruments outside of the Inter-American System, see, e.g., "Street Children" (Villagran Morales et al) v. Guatemala, 19 November 1999, IACrtHR, Merits, Series C No. 32 paras. $192-95$.

33 For an enumerative list of the treaties that-within the Inter-American System-have recognized the competence of the Commission, and the Court, for the reception of the individual complains, see Article 23 of the Rule of Procedure of the Inter-American Commission on Human Rights.

34 See Sarayaku v. Ecuador, supra note 30, para. 161. For further readings, see (Haeck et al. 2015).

35 The Right to Information on Consular Assistance, supra note 19, para. 115. See also Rights and Guarantees of Children, supra note 7 , para. 60.

36 Juridical Condition and Rights of Undocumented Migrants, 17 September 2003, IACrtHR, Advisory Opinion OC-18/03, Series A No. 18, Concurring Opinion of Judge Cançado, para. 85. 
Furthermore, it is important to highlight that the systemic integration of the corpus juris of international human rights law does not only strengthen the coherency and reduce the fragmentation of international law's responses to human rights related cases, but also provides enhanced tools for the protection of persons or groups in situations of vulnerability. It is in this interpretative framework-for instance- - that the court has acknowledged that migrant children find themselves "in a special condition of vulnerability." ${ }^{\prime 37}$

\subsection{The Relevance of the Pro-Homine Principle and the Effective Protection of Rights}

As a result of the hermeneutical focus on the object and purpose of a human rights treaty, the effective protection of human rights becomes intimately connected to the pro homine principle, also referred to as the pro persona principle (Medina Quiroga 2009; Miranda Bonilla 2015). In other words, human rights treaties need to be interpreted "in accordance with the canons and practice of International Law in general, and with International Human Rights Law, specifically, and [in a way] which awards the greatest degree of protection to the human beings under its guardianship." ${ }^{\prime 38}$

The American Convention does not constitute an exception to this principle. In fact, according to the regional tribunal:

"[T]he American Convention expressly establishes specific standards of interpretation in its Article 29, which includes the pro persona principle, which means that no provision of the convention may be interpreted as restricting the enjoyment or exercise of any right or freedom recognized by virtue of the laws of any state party or by virtue of another convention to which one of the said states is a party, or excluding or limiting the effect that the American Declaration of the Rights and Duties of Man and other international acts of the same nature may have." 39

Hence, the pro persona principle constitutes an essential interpretative tool, which-combined with the evolutionary and systemic interpretation of the court-enlarges human rights' protection. Consequently, the systemic integration of international law applied by the court could not only result in the expansion of the human rights' protection in a specific case, but also on the prioritization and centrality of the individual's fate in the process of interpretation (De Oliveira Mazzuoli and Ribeiro 2016).

Among different groups in situations of vulnerability, the individual fate of children requires a special attention and enhanced levels of guarantees from state authorities. ${ }^{40}$ The IACrtHR has not exempted itself from this responsibility. On the contrary, following the hermeneutical guidelines of the pro-persona principle, it has developed a case law aimed at strengthening the conventional protection of children's rights. Unveiling the interpretative paths taken by the regional tribunal in cases related to children's rights will be the subsequent focus of this paper. In fact, children's extreme vulnerability justifies additional hermeneutical efforts in order to support the development of more adequate and effective legal solutions able to match their quest for justice in the Americas.

\section{Systemic Integration of IHRL in the Case of Children's Rights}

Under the American Convention, children's rights are explicitly mentioned in Article 19, which establishes the right of every child to "measures of protection required by his condition as a minor on the part of his family, society, and the state." In the eyes of the IACrtHR, this provision "should respond to the new circumstances in which it will be projected and one that addresses the needs of the

37 Rights and Guarantees of Children, supra note 7, para. 155.

38 Case of Benjamin et al. v. Trinidad and Tobago, 1 September 2001, IACrtHR, Preliminary Objections, Series C. No. 81, para. 70. See also (Pasqualucci 2013).

39 Rights and Guarantees of Children, supra note 7, para. 54.

40 See (IACHR 2011, 2013b, 2017). 
child as a true legal person, and not just as an object of protection," 41 taking into consideration "the changes over time and present-day conditions." 42

Since its first judgement regarding the application of Article 19 ACHR, in the case of the "Street Children" (Villagran-Morales et al.) v. Guatemala," ${ }^{33}$ the IACrtHR has built an interpretative framework able to deliver an effective protection of children's rights, based on the evolutive and systemic interpretation of the provisions contained in the above-mentioned norm. In particular, the court has systemically reinforced and integrated the international protection to children's rights by reaffirming the hermeneutical principle that "when interpreting a treaty, not only the agreements and instruments formally related to it should be taken into consideration (Article 31.2 of the Vienna Convention), but also the system within which it is (inscribed) (Article 31.3)." ${ }^{\prime 4}$

Following this judgment, the court has elaborated in recent years, a landmark jurisprudence on children's rights based on the expansive and non-restrictive interpretation of Article 19 ACHR. Indeed, as a result of this systemic approach, the court has made references to the interrelations that Article 19 ACHR has with other relevant provisions of ACHR (internal integration), but also to other relevant documents and instruments that integrate the corpus juris of IHRL (external integration).

For instance, by means of an internal integration, the court took into consideration other interconnected and interrelated provisions of the American Convention, such as the right to life (Article 4), the right to humane treatment (Article 5), the right to fair trial (Article 8) and judicial protection (Article 25) (Feria Tinta 2008). Therefore, by interpreting the scope of protection of Article 19 ACHR in connection with other provisions enshrined within the American Convention, the court has enhanced the protection of the rights of children by means of an internal systemic integration of this regional instrument, based on the interconnection and interrelation between conventionally protected rights (Feria Tinta 2007).

In addition to the above-mentioned internal integration of the convention, the regional tribunal has further reinforced children's rights protection by means of an external integration of the later instrument, under the light of the relevant instruments that are an integrative part of the corpus juris of international human rights law. In particular, the court was able to identify and provide content to the corresponding states' obligations for the protection of children's rights, within the normative framework of the American Convention, by means of reading Article 19 ACHR under the light of the fundamental principles enshrined in the CRC. For instance, the court has acknowledged on several occasions, the relevance of the principle of the best interest of the child-as respected by the CRC ${ }^{45}$ under a wide array of different factual situations that put the ACHR in contact with other relevant instruments part of the corpus juris of international human rights law, such as in the contexts of armed conflicts, ${ }^{46}$ forced disappearances ${ }^{47}$ and migration. ${ }^{48}$ Hence, we can do nothing but conclude that the IACrtHR has further developed the protection of children's rights afforded by the ACHR under the interpretative guidelines provided by its systemic interconnection and interrelation with other instruments that integrate the same international normative system. ${ }^{49}$

41 Juridical Condition and Human Rights of the Child, 28 August 2002, IACrtHR, Advisory Opinion OC-17/02, Series A No. 17, para. 28.

42 Ibid, para. 21.

43 "Street Children" (Villagran Morales et al) v. Guatemala, 19 November 1999, IACrtHR, Merits, Series C No. 32.

44 Ibid, para. 192.

45 E.g., Gomez-Paquiyauri Brothers v. Peru, supra note 26, para 163.

46 See-among others-Case of Vargas Areco v. Paraguay, 26 September 2006, IACrtHR, Merits, Reparations and Costs, Series C No.155 and Case of Santo Domingo Massacre v. Colombia, 30 November 2012, IACrtHR, Preliminary Objections, Merits and Reparations, Series C No. 250.

47 See Case of Gelman v. Uruguay, 24 February 2011, IACrtHR, Merits and Reparations, Series C No. 215.

48 See, e.g., Pacheco Tineo Family v. Plurinational State of Bolivia, supra note 5 and Case of the Expelled Dominicans and Haitians $v$. Dominican Republic, 28 August 2014, IACrtHR, Preliminary Objections, Merits, Reparations and Costs, Series C No. 282.

49 In the words of the court: "Article 19 of the convention, in addition to granting special protection to the rights recognized therein, establishes a state obligation to respect and ensure the rights recognized to children in other applicable international instruments." Case of the Pacheco Tineo Family v. Plurinational State of Bolivia, supra note 5, para. 219. 
A clear example of this systemic approach can be found in the above-mentioned "Street Children" case, where the court made its first interpretative references to the Convention on the Rights of the Child. In this case, the court highlighted a number of provisions of the CRC that should be taken into consideration for the determination of the "measures of protection" referred by Article 19 ACHR. Among these provisions, the regional tribunal has identified-for instance-the importance of the non-discrimination principle; the special assistance for children deprived of their family environment; the guarantee of survival and development of the child; the right to an adequate standard of living and the social rehabilitation of all children who are abandoned or exploited. ${ }^{50}$

In addition to its contentious jurisdiction, the court has also resorted to systemic references in one of its most influential advisory opinions; that is, the Advisory Opinion on the Juridical Condition and Human Rights of the Child (2002). ${ }^{51}$ In this obiter dictum, the court identified a list of provisions of the CRC that should be taken into consideration as reference points for states when ensuring the effective realization of all rights of children. Among these provisions, the court has highlighted the specific importance of Article 3 (best interests of the child); Article 9 (separation from parents); Article 18 (parental responsibilities and state assistance); Article 20 (children deprived of family environment); Article 21 (adoption); Article 37 (detention and punishment); and Article 40 (juvenile justice). ${ }^{52}$

As an additional development of this jurisprudential approach, it would be important to mention the Advisory Opinion on the Rights and Guarantees of Children in the Context of Migration an/or in Need of International Protection (2014). ${ }^{53}$ Under the light of the fundamental principles of the CRC, the court has identified several obligations that states should comply with in order to achieve a "system of comprehensive protection" of children rights under Article 19 of ACHR. ${ }^{54}$

Therefore, in order to better understand the systemic integration of the regional standards for the protection of the rights of children, it becomes necessary to critically analyze the hermeneutical steps taken by the court when referring to the relevance of universal, regional and domestic norms-with binding or non-binding characters-under its conventional mandate (Tigroudja 2013, p. 466). In this regard, special attention will be given in the following section to the praetorian development of the notion of the corpus juris of international human rights law for the protection of children's rights. ${ }^{55}$

\subsection{The Corpus Juris for the Protection of Children's Rights}

As introduced in the previous sections, through the systemic integration of international law, the court drew interpretative inspiration and —-to certain extent—applied other instruments that are part of the corpus juris of international human rights law while interpreting the scope of protection of conventionally recognized children's rights. And, even most importantly, by doing so the court has expressly acknowledged the existence of an international corpus juris for the protection of children's rights. ${ }^{56}$

Since the adoption of the "Street Children" case, the Inter-American Court has recognized that both the American Convention and the Convention on the Rights of the Child form part of a very comprehensive international corpus juris for the protection of the rights of the child, which helps to

\footnotetext{
"Street Children" (Villagran Morales et al) v. Guatemala, supra note 32, para. 196.

Juridical Condition and Human Rights of the Child, 28 August 2002, IACrtHR, Advisory Opinion OC-17/02, Series A No. 17. Ibid, para. 59.

33 Rights and Guarantees of Children in the Context of Migration and/or in Need of International Protection, 19 August 2014, IACrtHR, Advisory Opinion OC-21/14, Series A No. 21. For further studies on this advisory opinion see-among others-(Arlettaz 2016).

54 Rights and Guarantees of Children, supra note 53, para. 69.

55 For an in deep study in this matter, see-for example-(Nola and Kilkelly 2016; Aguilar Cavallo 2008).

56 See, e.g., Case of Forneron and daughter v. Argentina, 27 April 2012, IACrtHR, Merits, Reparations and Costs, Series C No. 242, para. 44.
} 
determine and further clarify "the content and scope of the general provision established in Article 19 of the American Convention." ${ }^{57}$ As stated by the regional tribunal:

"[T]he Court has repeatedly stressed the existence of a very comprehensive corpus juris of international law on the protection of the rights of the child, which the court must use as a source of law to establish 'the content and scope' of the obligations that states have assumed under Article 19 of the American Convention with regard to children; particularly, by specifying the 'measures of protection' to which this article refers." ${ }^{\prime 58}$

Further, while referring to the corpus juris of international law on the protection of the rights of the child, the court has highlighted that CRC is the most universally ratified treaty, reflecting in this way "a broad international consensus (opinio iuris comunis) favorable to the principles and institutions protected by this instrument." ${ }^{59}$ In this regard, "the principles and rights recognized therein undoubtedly contribute decisively to establishing the scope of the American Convention when the individual entitled to the rights is a child." ${ }^{\prime 60}$

In fact, the relevance of the CRC in the integration of the child related provisions of the ACHR emerges, as evident from the case law of the court. However, the CRC is not the only instrument used by the regional tribunal in its systemic integration of the corpus juris of children's rights. ${ }^{61}$ For instance, in the context of children and migration, the relevance of the 1951 Refugee Convention ${ }^{62}$ and its 1967 Protocol $^{63}$ together with the regional definition of refugee of the Cartagena Declaration, ${ }^{64}$ have been highlighted by the court as integrative part of the international corpus juris. ${ }^{65}$

In addition, and even more importantly in the context of this paper, the systemic interpretation of Article 19 ACHR has paved the way for the identification and further clarification of the specific obligations that states have in relation to children and their families within migration processes (Dembour 2015; Beduschi 2018). To put it differently, the integration of the American Convention under the light of the provisions contained within the corpus juris for the protection of children's rights, was the hermeneutical tool that allowed the court to identify and further develop concrete procedural and substantive safeguards centered on delivering the most effective protection of the rights of children involved in a given case (effet utile). ${ }^{66}$

\subsection{States' Main Obligations for the Effective Protection of Children's Rights}

Under the normative framework of the American Convention, member states have not only assumed general obligations to respect, protect and fulfil conventionally recognized rights, ${ }^{67}$ but also specific obligations regarding children's rights aiming at enhancing the effective protection of their rights. ${ }^{68}$ Regarding the former, the first obligation that states assume under the convention is to respect

\footnotetext{
7 See Case of the "Street Children," supra note 32, para. 194 and Juridical Condition and Human Rights of the Child, supra note 51, para. 24.

58 Rights and Guarantees of Children, supra note 7, para. 57.

59 Ibid.

60 Ibid.

61 See (IACHR 2008).

62 Convention Relating to the Status of Refugees, adopted on 28 July 1951, entered into force on 22 April 1954

631967 Protocol to the 1951 Geneva Convention Relating to the Status of Refugees, adopted on 31 January 1967 and entered into force on 4 October 1967.

64 Cartagena Declaration on Refugees, adopted by the "Colloquium on the International Protection of Refugees in Central America, Mexico and Panama: Legal and Humanitarian Problems," held in Cartagena, Colombia, from 19 to 22 November 1984.

65 Rights and Guarantees of Children, supra note 7, para. 249.

66 See-among others-Gomez-Paquiyauri Brothers v. Peru, supra note 26, para. 151.

67 The Inter-American Court has addressed, on several occasions under its contentious jurisdiction, the scope of states' obligations to respect, protect and fulfil human rights. See e.g., Velásquez Rodríguez v. Honduras, 29 July 1988, IACrtHR, Merits, Series C No. 4 and Yean and Bosico Girls v. Dominican Republic, 8 September 2005, IACrtHR, Preliminary Objections, Merits, Reparations and Costs, Series C No. 130. See also (IACHR 2013a).

68 See Rights and Guarantees of Children, supra note 7, title VI. See also (IACHR 2017, pp. 32-62).
} 
and ensure human rights "to all persons subject to their jurisdiction" without any discrimination (Article 1(1) ACHR). ${ }^{69}$ On several occasions, the court has acknowledged that this provision imposes on states, the obligation to guarantee the effective exercise and enjoyment of rights to all individuals regardless of the person's nationality, residency or migratory status. ${ }^{70}$

In addition, states are also obliged to comply with Article 2 ACHR; that is, to adapt their domestic legal systems to the provisions enshrined in the American Convention. ${ }^{71}$ In other words, according to the principle of effet utile, national norms (including constitutional provisions) should contribute to the effective realization of conventional rights, which include the abrogation or modification of laws that could result in any type of discrimination or could prevent or otherwise restrict the effective implementation of conventional norms. ${ }^{72}$ In the wording of the court, "States not only have the positive obligation to adopt the necessary legislative measures to ensure the exercise of the rights established in this instrument (ACHR), but they must also avoid promulgating those laws that prevent the free exercise of these rights and avoid the elimination or amendment of laws that protect them."73

The general states' obligations to respect, protect and guarantee have been further specified in connection with those particular situations that deserve special attention from state authorities, such as in the case of persons or groups in situation of vulnerability (Lavrysen 2014, pp. 113-14). ${ }^{74}$ For instance, in the case of children, the Inter-American Commission of Human Rights (IACHR) ${ }^{75}$ has also repeatedly referred to the need to adopt domestic legislation in accordance with the CRC and the corpus juris of the rights of the child in conjunction with measures that prevent any type of violation and guarantee the effective exercise of children's rights without discrimination. ${ }^{76}$ The IACHR has identified positive obligations that state authorities should put in place-within their domestic jurisdictions-in order to fulfil children's rights. These measures include the need to implement different types of policies and strategies, ${ }^{77}$ together with the introduction of a wide array of legislative, administrative, social and educational measures aiming at enhancing the effective level of protection of children's rights. ${ }^{78}$ Further, state authorities should guarantee effective institutional protection, by means of introducing or developing mechanisms or institutions in charge of the implementation and execution of those policies, as well as their monitoring and evaluation. ${ }^{79}$

Article 19 ACHR has not been an exception regarding the development of states' obligations for the specific protection of children's rights. The interpretative centrality of Article 19 ACHR has been clearly acknowledged by the court when recognized that this provision "concerns the obligation to

69 Article I ACHR (Obligation to Respect Rights) states that: “(1) The state's parties to this convention undertake to respect the rights and freedoms recognized herein and to ensure to all persons subject to their jurisdiction the free and full exercise of those rights and freedoms, without any discrimination for reasons of race, color, sex, language, religion, political or other opinion, national or social origin, economic status, birth, or any other social condition."

70 Rights and Guarantees of Children, supra note 7, para. 62.

71 Article II ACHR (Domestic Legal Effects) reads as follows: "Where the exercise of any of the rights or freedoms referred to in Article 1 is not already ensured by legislative or other provisions, the state's parties undertake to adopt, in accordance with their constitutional processes and the provisions of this Convention, such legislative or other measures as may be necessary to give effect to those rights or freedoms."

72 Rights and Guarantees of Children, supra note 7, para. 65.

73 Pacheco Tineo Family v. Plurinational State of Bolivia, supra note 5, para. 236.

74 Case of Perozo et al. v. Venezuela, 28 January 2009, IACrtHR, Preliminary Objections, Merits, Reparations and Costs, Series C No. 195.

75 The Inter-American Commission was created by Resolution VIII, of the Fifth Meeting of Consultation of Ministers of Foreign Affairs, held in Santiago de Chile, in 1959. See for further readings regarding the Inter-American Commission-among others (Goldman 2009).

76 See (IACHR 2017).

77 For an in-depth study on this matter, see (IACHR 2017). The Inter-American Commission refers to a wide array of policies, including basic social policies or universal policies (which involve all children, such as health and education plans), social development policies (necessary to overcome situations of vulnerability, inequality or exclusion), special protection policies (for minors in an specific risk situation) and legal defense policies (aimed at building a specialized justice system for children).

78 Ibid, pp. 32 et seq. See also Committee on the Rights of the Child, General Comment No. 5, General measures of implementation of the Convention on the Rights of the Child (Articles 4, 42 and 44 paragraph 6), 2003.

79 See (IACHR 2017). 
adopt measures of protection in favor of all children, based on their condition as such, and this has an impact on the interpretation of all the other rights established when the case relates to children." 80 Thus, state authorities should provide enhanced level of protection to children, which need to take into consideration their specific situation of vulnerability. As stated by the court,

"The protection due to the rights of the child, as subjects of law, must take into consideration their intrinsic characteristics and the need to foster their development, offering them the necessary conditions to live and develop their aptitudes taking full advantage of their potential. [...] For this reason, the convention stipulates that the pertinent measures of protection for children must be special or more specific than those established for the rest of the population; i.e., the adults." ${ }^{\prime 81}$

In other words, Article 19 ACHR should be understood as an additional, supplementary protection that reinforces the scope of protection of other rights when their beneficiaries are children, due to the fact that their physical and emotional development requires special protection. ${ }^{82}$ Based on this premise, it would be possible not to conclude - together with the regional tribunal-that the American Convention vests "a preferential treatment for children, precisely because of their special vulnerability, and in this way, endeavors to provide them with the adequate mechanism to achieve the effective equality before the law enjoyed by adults, owing to their condition as such." 83

In fact, following its pronouncement on the case of the "Street Children," the Inter-American Court has analyzed in numerous occasions the content and extent of "measures of protection" —and the correspondent states' obligations-considering, as mentioned above, the Convention on the Rights of the Child as the most suitable instrument for the interpretation of Article 19 ACHR. ${ }^{84}$ In this sense, the systemic integration of the convention under the provisions of the corpus juris for the protection of the rights of the child has paved the way towards the identification of a wide array of obligations that states should comply with; in particular, under the light of the principles and norms contained in CRC. ${ }^{85}$ In the words of the court:

"When the protection of the rights of the child and the adoption of measures to achieve this protection is involved, the following four guiding principles of the convention on the rights of the child should transversely inspire and be implemented throughout every system of comprehensive protection: the principle of non-discrimination; the principle of the best interest of the child; the principle of respect for the right to life, survival and development; and the principle of respect for the opinion of the child in any procedure that affects her or him in order to ensure the child's participation." 86

The central question addressed by this jurisprudence is how to deliver effective protection to children's rights. As highlighted by the IACrtHR, measures contained in Article 19 shall include a comprehensive protection; "they must promote the full enjoyment of all rights recognized in the convention on the rights of the child and in other applicable instruments, especially the right to health, adequate nutrition, to education, as well as to play and the recreational activities appropriate for the child's age." ${ }^{87}$ Moreover, states should generate the necessary conditions that "guarantee a dignified

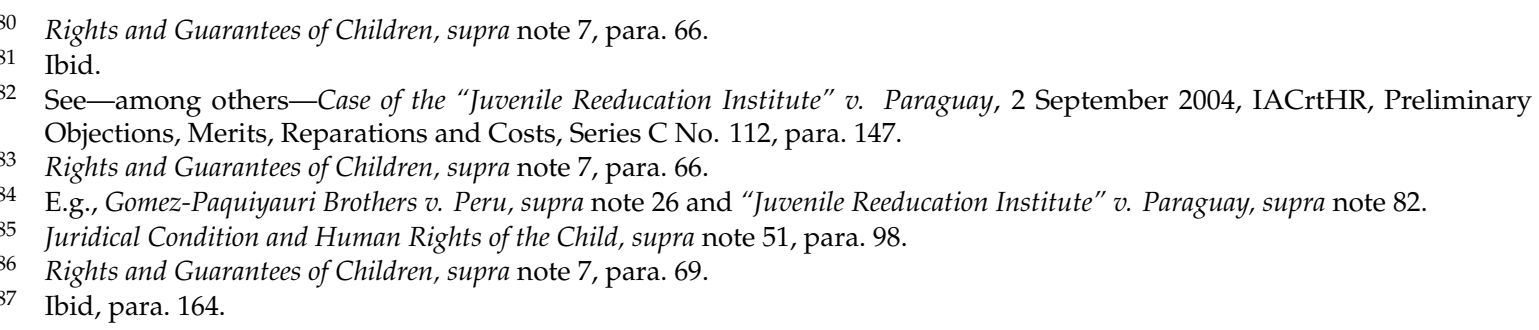


existence ${ }^{\prime \prime 8}$ and would allow children to develop a project of life. ${ }^{89}$ In this sense, state authorities are responsible for supporting children with building their life plan; that is, generating the societal conditions and institutional frameworks that could be conducive for their adequate development. ${ }^{90}$

These obligations are especially relevant vis-à-vis children in a particular situation of vulnerability, such as the case of children in the context of migration. In this regard, and perhaps even more importantly in connection with the aim of this paper, the regional tribunal has specifically stressed that states' obligations need to follow a 'human rights approach' while implementing immigration policies for children, taking into account both the protection and development of the child..$^{91}$

In fact, in connection with states' obligations towards migration, it is adequate to say that state authorities have the obligation to assure the fulfilment of the principle of the best interest of the child within migration processes and-in particular-during the enactment of state's policies that could directly or indirectly affect the wellbeing of migrant children. ${ }^{92}$ Thus, any judicial or administrative decision related to the entry, stay, detention or expulsion of the child, or his or her family, should take due consideration of the hermeneutical centrality of this principle. ${ }^{93}$ In addition, the court has expressly identified states' specific obligations-derived from the corpus juris for the protection of the child-aiming at ensuring the respect and fulfilment of the rights of unaccompanied or separated children in migration proceedings. In this sense, it would be possible to mention the duties of state authorities in relation to the appropriate arrangements regarding the reception and accommodation of migrant children; determinations of their identities and compositions of their families; enquiries of the whereabouts of family members; and facilitation of family reunification, all in accordance with the best interest principle, which also includes giving adequate consideration to the views of the unaccompanied child..$^{94}$

Hence, we can do nothing but conclude that the expansive interpretation of states' obligations in relation to the measures of protection contained in Article 19 ACHR shows a clear awareness of the specific needs of the protection of children in the Americas, by the regional tribunal. Thus, the court has repeatedly highlighted the need to adopt special measures regarding the protection of children, which has been translated into concrete obligations upon state authorities. In this sense, the systemic integration of the American Convention, under the light of the corpus juris of international human rights law, has also paved the way for the recognition of a specific set of minimum guarantees afforded to children in the context of migration processes, independently of other legal conditions, such as the migration status of their family members. ${ }^{95}$

\section{Effective Guarantees for the Protection of Children in the Context of Migration Processes}

As introduced above, the Inter-American Court has developed an important case law regarding human rights of children with special focus on child migrants (Olmos Giupponi 2017). One of the key elements of this jurisprudence is the strengthening of procedural guarantees, as enshrined in Articles 8 (Right to a Fair Trial) and 25 (Right to Judicial Protection) ACHR. In fact, these rights, which are equally recognized for all persons under the jurisdiction of the court "must be correlated with the specific rights established in Article 19, in such a way that they are reflected in any administrative or judicial

88 "Street Children" v. Guatemala, supra note 32, para. 144.

89 In fact, IACrtHR has understood that: "The ultimate objective of protection of children in international instruments is the harmonious development of their personality and the enjoyment of their recognized rights. It is the responsibility of the state to specify the measures it will adopt to foster this development within its own sphere of competence and to support the family in performing its natural function of providing protection to the children who are members of the family." Juridical Condition and Human Rights of the Child, supra note 51, para. 53.

90 See (IACHR 2017, para. 44).

91 Rights and Guarantees of Children, supra note 7, para. 68.

92 Ibid, para. 70

93 Ibid.

94 Ibid, para. 167.

95 See Pacheco Tineo Family v. Plurinational State of Bolivia, supra note 5, para. 224. 
proceedings where the rights of a child are discussed." ${ }^{\prime 96}$ In other words, effective access to justice, equality and due process need to be ensured, under the interpretative guidelines of the principle of the best interest of the child, as a primary consideration during administrative or judicial proceedings involving children. ${ }^{97}$

These jurisprudential developments could be explained partially by the flexible and innovative approaches that the IACrtHR has taken in connection with the exercise of its advisory jurisdiction (Pasqualucci 2014). In fact, the Advisory Opinion on the Juridical Condition and Human Rights of the Child (2002), together with the Advisory Opinion on The Right of Information in relation to Consular Assistance within the Framework of the Guarantees of Due Process of Law (1999) and the Advisory Opinion on The Juridical Condition and Rights of Undocumented Migrants (2003), have been considered foundational obiter dicta in the process of the humanization of international law, aiming at reinforcing the protection delivered to individuals (Cançado Trindade 2007).

The doctrinal line developed under the advisory jurisdiction, was consolidated and reinforced within it contentious jurisdiction, such as in the case Velez Loor v. Panama. ${ }^{98}$ In this case, the court specifically recognized that irregular migrants in detention are entitled to a set of minimum guarantees in light of the provisions contained within the international corpus juris of human rights for the protection of migrants' rights. ${ }^{99}$ Indeed, as a result of this integrative approach, specific rights for the protection of migrants have been acknowledged by the court, such as the rights to legal aid, information, effective access to consular assistance and appeal, among others. ${ }^{100}$ Moreover, in the case of Pacheco Tineo Family v. Bolivia, ${ }^{101}$ the court has reinforced the recognition of a set of fundamental guarantees-in line with several sources of international law-that states should observe in immigration proceedings, such as the obligation to provide the applicants with a competent interpreter, legal assistance or representation, and the opportunity to communicate with the United Nations High Commissioner for Refugees (UNHCR). ${ }^{102}$

Regarding the specific development of the rights of the child, the court made clear efforts in its Advisory Opinion on the Juridical Condition and Human Rights of the Child (2002) to integrate and reinforce the application of procedural guarantees provided by the American Convention to all proceedings involving children, by means of making interpretative references to CRC, the Standard Minimum Rules for the Administration of Juvenile Justice (Beijing Rules) ${ }^{103}$ the Standard Minimum Rules for Non-custodial Measures (Tokyo Rules) ${ }^{104}$ and the Guidelines for the Prevention of Juvenile Delinquency (Riyadh Guidelines). ${ }^{105}$ Among these guarantees, the court stressed the importance of the intervention of a competent, impartial and independent judicial body; ${ }^{106}$ the right to appeal and

96 Juridical Condition and Human Rights of the Child, supra note 51, para. 95. See also-among others-Case of Mendoza et al. v. Argentina, 14 May 2013, IACrtHR, Preliminary Objections, Merits and Reparations, Series C No. 220, para. 148.

97 See, e.g., Juridical Condition and Human Rights of the Child, supra note 51, para. 98. In fact, as recognized by Ortiz: "[I]n the light of the incorporation of the Convention on the Rights of the Child to the corpus juris, the Inter-American system has developed more specific parameters that provide content to the effective access to justice of children," (Ortiz 2015, p. 337).

98 Velez Loor v. Panama, 23 November 2010, IACrtHR, Preliminary Objections, Merits, Reparations and Costs, Series C No 218 See notably for a comprehensive analysis of the main findings of the case (Mason 2012).

99 Velez Loor v. Panama, supra note 98, para. 99.

100 Ibid, paras. 132, 153, 179.

101 In connection with the importance of this case in the jurisprudence of the IACrtHR, see (Arlettaz 2015).

102 Pacheco Tineo Family v. Plurinational State of Bolivia, supra note 5, para. 159.

103 United Nations Standard Minimum Rules for the Administration of Juvenile Justice (The Beijing Rules), UN Doc. A/RES/40/33, adopted on 29 November 1985.

104 United Nations Standard Minimum Rules for Non-custodial Measures (Tokyo Rules), UN Doc. A/RES/45/110, adopted on 14 December 1990.

105 United Nations Guidelines for the Prevention of Juvenile Delinquency (The Riyadh Guidelines), UN Doc. A/RES/45/112, adopted on 14 December 1990.

106 Juridical Condition and Human Rights of the Child, supra note 51, para.120. 
effective remedy; 107 and children's right to participation in accordance with the specific conditions of the child and his or her best interest. ${ }^{108}$

This development has been further consolidated with the identification of the need for the introduction of a differential treatment able to provide enhanced guarantees and level of protection to migrant children, based on the implementation of the principle of effectiveness. The important task of introducing specific procedural safeguards in the context of migration processes that take into account the needs of children within judicial procedures, was further developed by the court in the latter case of Pacheco Tineo Family. Accordingly, the regional tribunal highlighted in this decision that the fundamental principles enshrined in CRC should guide the substantial and procedural aspects of asylum procedures. ${ }^{109}$ Based on these considerations, the regional tribunal recognized that migrant children have the right to participate and express their opinion in asylum proceedings, but not only that. ${ }^{110}$ In fact, parallel to the substantive obligation to respect and fulfil this right, state authorities have the procedural obligation to enable and facilitate enjoyment by means of introducing and implementing adequate procedures for children, ${ }^{111}$ all in accordance with the "assessment, determination, consideration and protection of the best interest of the child."112 In the views of the court, the best interest principle 'should always prevail' when children are involved in asylum procedures in all decisions that affect them both directly or indirectly. ${ }^{113}$

As a corollary of these jurisprudential developments, the court has adopted one of its most influential advisory opinions in relation to child migrants' rights; that is, the Advisory Opinion on the Rights and Guarantees of Children in the Context of Migration and/or in Need of International Protection (2014). ${ }^{114}$ In fact, this decision has consolidated the importance of the pro-homine principle and systemic integration as hermeneutical tools that have paved the way for reading the American Convention under the light of both the corpus juris for the protection of children and the corpus juris for the protection of migrants. ${ }^{115}$

In particular, the court analyzed Article 1 (obligation to respect rights), Article 2 (domestic legal effects), Article 7 (right to personal liberty), Article 8 (right to fair trial), Article 19 (rights of the child) and Article 25 (right to judicial protection) ACHR in line with a wide array of relevant sources of international human rights law. Based on this integrative approach, the IACrtHR has developed a set of specific procedural guarantees that states should observe in immigration procedures which involve children. ${ }^{116}$ Indeed, through a dynamic, systemic and evolutive interpretation of the provisions of the American Convention under the light of provisions contained within the corpus juris of international human rights law, the IACrtHR has identified-among others-the obligation to provide children with a translator or interpreter free of charge; ${ }^{117}$ a legal representative; ${ }^{118}$ a guardian when the applicant is an unaccompanied or separated child; 119 and the opportunity to communicate with consular authorities. ${ }^{120}$ Moreover, the court has also analyzed children's rights to be notified of the existence of

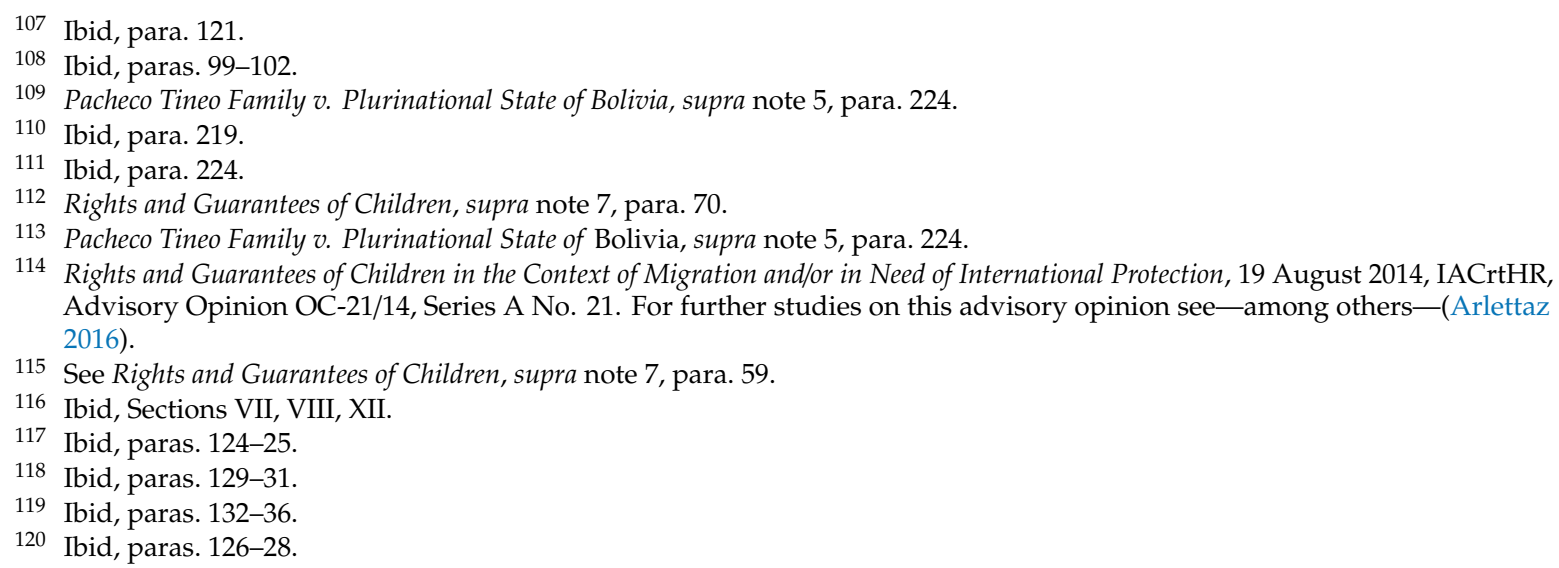


the proceedings and of the decisions adopted concerning entry, permanence or expulsion; ${ }^{121}$ the right of the child to immigration procedures conducted by a specialized official or judge; ${ }^{122}$ and the right to appeal before a judicial authority with suspensive effect. ${ }^{123}$

It is important to highlight that the recognition of most of the above-mentioned rights happened by means of highlighting the centrality and interpretative relevance of the CRC and its fundamental principles. In particular, the IACrtHR interpreted the right of the child to be heard and to participate in every stage of immigration proceedings in light of Article 12 (respect for the views of the child) CRC and in accordance with the interpretative guidance offered by the Committee on the Rights of the Child under its General Comment No. $12 .{ }^{124}$ These interpretative references facilitated the effective jurisprudential recognition of the principle that "children must be heard so that the decision taken accords with their bests interests." 125 To put it differently, state authorities should ensure under the American Convention that all processes related to children migrants conduce to the effective realization of their rights, in accordance with their best interests. ${ }^{126}$ For instance, state authorities should create the substantive and procedural conditions that guarantee an environment, which is not intimidating or inappropriate to the child, so that "the child feels respected and safe when expressing her or his views in an appropriate physical, mental and emotional environment." 127

Furthermore, the court has also referred extensively to children's right to personal liberty during immigration proceedings. In this sense, IACrtHR resorted to different international norms in order to support the development of the principle of non-deprivation of liberty of children based on their irregular migratory status. In fact, it is important to notice that the court did not only made references to the provisions of CRC but-additionally—-to other international instruments ${ }^{128}$ including 'soft law' international guidelines and recommendations, such as the UNCHR's Guidelines on the Applicable Criteria and Standards relating to the Detention of Asylum-Seekers and Alternatives to Detention, 129 the Beijing Rules and the Tokyo Rules. Based on these instruments, and on the evolution of the corpus juris of international human rights law, the regional tribunal has clearly indicated that "the deprivation of the liberty of a child in this context can never be understood as a measure that responds to the child's best interest." 130 The Court has categorically concluded that those kind of detentions are "arbitrary, and consequently, contrary to both the convention and the American Declaration."131

Lastly, it is noteworthy to highlight that in its latest advisory opinion on migration, that is, the Advisory Opinion on The institution of asylum, and its recognition as a human right under the inter-American system of protection (2018), the court has recognized that children are entitled to a differential treatment in

121 Ibid, paras. 117-19.

122 Ibid, paras. 120-21.

123 Ibid, paras. $140-42$.

124 United Nations Committee on the Rights of the Child, General Comment No. 12, The right of the child to be heard, 2009.

125 Rights and Guarantees of Children, supra note 7, para. 122. See for further readings regarding the labor of UN Committees in developing standards in connection to children in the context of migration: Committee on the Protection of the Rights of All Migrant Workers and Members of Their Families (CMW), Joint general comment No. 4 (2017) of the Committee on the Protection of the Rights of All Migrant Workers and Members of Their Families and No. 23 (2017) of the Committee on the Rights of the Child on State obligations regarding the human rights of children in the context of international migration in countries of origin, transit, destination and return, CMW/C/GC/4-CRC/C/GC/23, 16 November 2017.

126 In the words of the Court: "[A]ny immigration policy that respects human rights, as well as any administrative or judicial decision concerning the entry, stay or expulsion of a child, or the detention, expulsion or deportation of her or his parents associated with their own migratory status, must give priority to the assessment, determination, consideration and protection of the best interests of the child concerned." Rights and Guarantees of Children, supra note 7, para. 70.

127 Ibid, para. 123.

128 The Court considered the concept of deprivation of liberty in a broad sense in line with international human rights law while referring for instance to Article 4 (2) of the Optional Protocol to the Convention against Torture and other Cruel, Inhuman and Degrading Treatment or Punishment, adopted on 9 January 2003, entered into force 22 June 2006.

129 United Nations High Commissioner for Refugees (UNHCR), Guidelines on the Applicable Criteria and Standards relating to the Detention of Asylum-Seekers and Alternatives to Detention, 2012.

130 Rights and Guarantees of Children, supra note 7, para. 154.

131 Ibid. 
asylum procedures. ${ }^{132}$ In this sense, the regional tribunal stressed the importance of states' obligations to adapt asylum procedures to the specific needs of children and adolescents. ${ }^{133}$

To conclude, it would be possible to say that the rationale of these decisions could be found on the emphasis made by IACrtHR in connection with the special condition of vulnerability of migrant children and the need to address this situational condition by reinforcing the effective protection of their rights. As it will be described within the following paragraphs, specific procedural guarantees afforded to children within immigration proceedings are nothing but a concrete realization of this general rule. ${ }^{134}$

\subsection{Expanding States' Positive Obligations: The Case of Unaccompanied Children}

As critically analyzed throughout this paper, the systemic integration of the American Convention's provisions for the protection of children's rights, under the light of the specific norms and principles enshrined within the corpus juris of international human rights law, has led towards the development of a more effective and 'children friendly' regional jurisprudence. In fact, while examining states' obligations towards children involved within migration processes, the court has highlighted on numerous occasions, how important it is to pay attention to their special situation of vulnerability in order to provide effective measures of protection (Beduschi 2018).

In other words, the intrinsic vulnerability connected with the condition of being a child migrant, considered under the interpretative light of the pro persona principle, justifies the increased levels of protection afforded by the convention together with the identification of tightness obligations over state authorities' shoulders. ${ }^{135}$ This interpretative rule is—of course-fully applicable to the case of unaccompanied migrant children, ${ }^{136}$ in which their specific condition of vulnerability requires from state authorities, higher levels of protection by means of introducing additional safeguards. ${ }^{137}$ In fact, while referring to the personal factors of the child that lead to specific supplementary positive obligations from states, the court expressly highlighted the situation of vulnerability of the child who is separated or unaccompanied. ${ }^{138}$ To put it differently, the effective implementation of the rights enshrined in the convention requires taking into special consideration all circumstances of the unaccompanied child when deciding over the extension and scope of protection of those rights. This is nothing but the contextual application of the principle of the effect utile. ${ }^{139}$ As highlighted by the regional tribunal,

"The Court will also place special emphasis on those conditions and circumstances in which migrant children may find themselves in a situation of additional vulnerability that entails an increased risk of violation of their rights so that the state must adopt measures to prevent

132 The institution of asylum, and its recognition as a human right under the inter-American system of protection (interpretation and scope of Articles 5, 22(7) and 22(8) in relation to Article 1(1) of the American Convention on Human Rights), 30 May 2018, IACrtHR, Advisory Opinion OC-25/18, Series A No. 25.

133 Ibid, para. 99.

134 As mentioned by the court, "In view of the special condition of vulnerability of child migrants in an irregular situation, states are obliged, under Articles 19 of the American Convention and VII of the declaration, to choose measures that promote the care and well-being of the child to ensure its comprehensive protection, rather than the deprivation of her or his liberty." Rights and Guarantees of Children, supra note 7, para. 155.

135 See-among others-Nadege Dorzema et al. v. Dominican Republic, 24 October 2012, IACrtHR, Merits, Reparations and Costs, Series C No. 251, para. 152 and Pacheco Tineo Family v. Plurinational State of Bolivia, supra note 5, paras. 217-19.

136 See Rights and Guarantees of Children, supra note 7, paras. 89-93.

137 Ibid, para. 167. See also Committee on the Rights of the Child, General Comment No. 6, Treatment of unaccompanied and separated children outside their country of origin, 2005 and Committee on the Rights of the Child, General Comment No. 14 on the right of the child to have his or her best interests taken as a primary consideration (art. 3, para. 1), 2013.

138 See Rights and Guarantees of Children, supra note 7, para. 71.

139 See-among others-Case of the Xákmok Kásek Indigenous Community v. Paraguay, 24 August 2010, IACrtHR, Merits, reparations and costs, Series C No. 214, para. 250 and Velez Loor v. Panama, supra note 98, para. 99. 
and reverse this type of situation as a priority, as well as to ensure that all children, without exception, may fully enjoy and exercise their rights under equal conditions." 140

The hermeneutical relevance of the above-mentioned principles, in order to guarantee the effective protection and realization of children's rights within the context of asylum procedures, has been highlighted by the court in its jurisprudence constant. ${ }^{141}$ In this sense, one of the main procedural safeguards afforded to children is to determine their special condition, not only as minors but also to determine whether they are unaccompanied or separated from their families. ${ }^{142}$ Indeed, based on the provisions contained in the CRC and the guidelines set by the Committee on the Rights of the Child, ${ }_{1}^{143}$ the court concluded that owing to the high vulnerability that affect children who are unaccompanied, the determination procedure should be done immediately upon arrival, as these minors are exposed to severe risks (such as child trafficking, exploitation and abuse) that could seriously affect them. ${ }^{144}$ In addition to the determination of their current status as unaccompanied children, state authorities are also responsible for tracing their family members, and if possible, to seek and facilitate the reunification of unaccompanied children with their families as soon as possible, as required by the principle of the best interest of the child. ${ }^{145}$

Within this context, the court has also emphasized the need to enable unaccompanied children to participate in every stage of the proceedings and to guarantee their right to effective access to legal assistance, including consular support from the diplomatic delegations of their country of origin that exist in the country of transit or destination where children are located. ${ }^{146}$ In this sense, international human rights law and-in particular-children's rights, intersect with migration norms and consular relations' provisions, providing a systemic normative framework (i.e., corpus juris) able to deliver an integrative protection to unaccompanied children in the context of migration processes (Fuentes 2018).

Further, among the positive obligations that states have to adopt towards this vulnerable group, the duty to appoint unaccompanied children with a guardian as soon as possible has been identified; that is, as soon as their condition as unaccompanied is determined. ${ }^{147}$ Moreover, state authorities are equally responsible for monitoring the quality and exercise of these guardianships, ${ }^{148}$ "in application of the principle of the effet utile and the needs for protection in cases of persons or groups in a vulnerable situation." ${ }^{149}$ Finally, the right to the appointment of a guardian has been also recognized in cases where unaccompanied children are deprived of their liberty due to migration reasons. ${ }^{150}$ In this context, state parties have to provide unaccompanied children with both a legal representative and a guardian, and guarantee the right to information and communication between them. ${ }^{151}$

At this point, it is important to clarify that, in the case of migrant children that are unaccompanied or separated from their family, the regional tribunal has stressed that the deprivation of liberty is inappropriate. ${ }^{152}$ The rationale behind this inter dictum of the court resides in the fact that states have the positive obligation to prioritize the adoption of measures of special protection "based on the principle of the best interest of the child, assuming its position as guarantor with the greatest care and responsibility." 153 In other words, this restrictive approach is nothing but a direct consequence of the

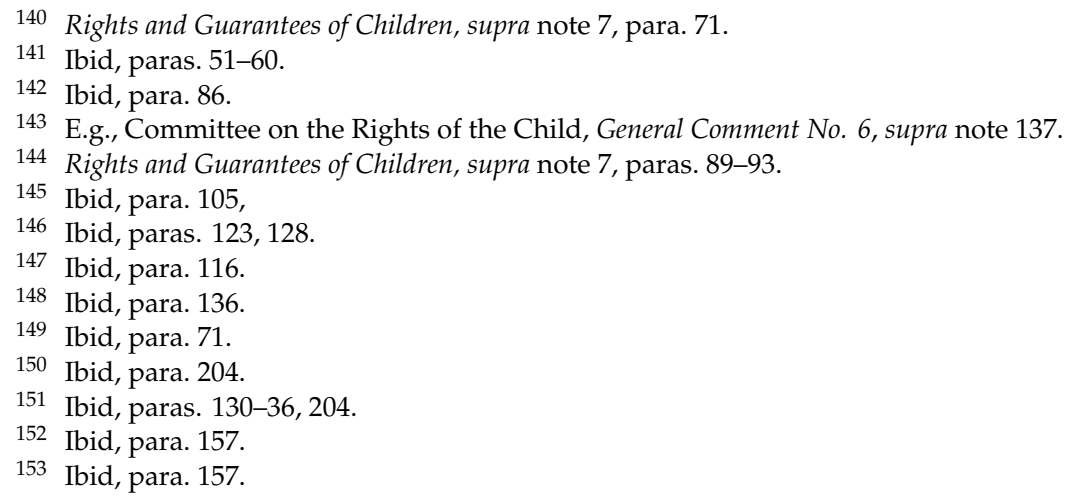


hermeneutical integration of the American Convention with the provisions stipulated by the corpus juris for the protection of the rights of the child.

To conclude, it is important to mention-as an additional consequence of the effective implementation of the pro-persona principle in the context of child's rights-the fact that state authorities are also responsible for providing adequate accommodation to unaccompanied children, due to their situation of vulnerability. Moreover, the court has identified several safeguards and guidelines in relation to reception arrangements in order to guarantee-for instance-that unaccompanied children are never accommodated with adults, ${ }^{154}$ or-even more importantly-that accommodation arrangements fulfil the basic conditions necessary for the "holistic development" of children based on the "principle of the child's best interest and comprehensive protection."155

\subsection{Hermeneutical Integration of the Corpus Juris of Migrants for the Protection of Unaccompanied Children}

As mentioned above, the American Convention demands the introduction of specific positive obligations that could enable or facilitate the effective enjoyment of the conventionally protected rights by persons or groups of individuals in a situation of vulnerability. In fact, the regional tribunal has adopted a human rights approach towards migration and children's rights, continuously emphasizing the special situation of vulnerability and the consequent need of special measures regarding the protection of migrants. ${ }^{156}$ As stated by the regional tribunal, "Based on the special needs for protection of migrants, this Court interprets and provides content to the rights that the convention recognizes to them, in keeping with the evolution of the international corpus juris applicable to the human rights of migrants." 157

In this sense, refugee law and the rights of migrants are also considered as an integrative part of this corpus juris, and-therefore- their relevant provisions could be utilized for the clarification of the extension and scope of protection of the rights recognized in the convention. The expansion of the scope of protection of key conventional provisions has been a tangible result of this interpretative approach. ${ }^{158}$ Among these provisions, it is possible to mention Article 8 (right to a fair trial); Article 25 (right to judicial protection); Article 22 (freedom of movement and residence, right to seek and be granted asylum and non-refoulement); and Article 19 (rights of the child) ACHR.

Regarding the specific integration of the provisions of the convention for the protection of the rights of migrants, it is essential to refer to one of the most important advisory opinions delivered by the court; that is, the Advisory Opinion on the Juridical Condition and Rights of Undocumented Migrants (2003). ${ }^{159}$ In this additional obiter dictum, the regional tribunal has emphasized states' obligations to adopt special measures able to ensure the effective enjoyment of human rights of migrants. ${ }^{160}$ In particular, the court stressed that all rights recognized in the ACHR, such as the right of access to justice for all persons-including of course children, are preserved "irrespective of the migratory status of the protected persons." ${ }^{\prime 161}$ To put it differently, the regular or irregular migratory status of an individual under a given national legal system cannot be used to prevent migrants from the enjoyment of their fundamental rights. In the words of the regional tribunal, the protection afforded by the

\footnotetext{
154 Ibid, paras. 176-79.

155 Ibid, para. 181.

156 E.g., The Right to Information on Consular Assistance, supra note 19, Velez Loor v. Panama, supra note 98, Pacheco Tineo Family v. Plurinational State of Bolivia, supra note 5.

157 Pacheco Tineo Family v. Plurinational State of Bolivia, supra note 5, para. 129.

158 See-among others-Pacheco Tineo Family v. Plurinational State of Bolivia, supra note 5.

159 Juridical Condition and Rights of Undocumented Migrants, 17 September 2003, IACrtHR, Advisory Opinion OC-18/03, Series A No. 18. For further studies on this advisory opinion see-among others-(Lyon 2004; Beduschi 2015).

160 Juridical Condition and Rights of Undocumented Migrants, supra note 159, para. 117.

161 Ibid, para. 118
} 
convention is guaranteed "without any discrimination owing to their regular or irregular residence, or their nationality, race, gender or any other reason."162

Unaccompanied child migrants are not and could not be seen as an exception to this rule. As mentioned above, their specific situation of vulnerability demands-on the contrary-the introduction of specific legislative and administrative measures able to guarantee their effective protection. In their particular case, the principle of equality and non-discrimination demands state authorities to treat unaccompanied migrant children differently; that is, providing them with a differential treatment (positive actions) that would fully address their vulnerable condition. ${ }^{163}$ As indicated by the court, "no discrimination exists if the difference in treatment has a legitimate purpose and if it does not lead to situations which are contrary to justice, to reason or to the nature of things."164

In the case of the unaccompanied migrant child, the application of the pro-persona principle requires from state authorities to take all necessary measures that take into consideration their specific situation of vulnerability, under the interpretative guideline of the best interest of the child principle. In this sense, it would be possible to conclude-together with the European Court of Human Rights (ECrtHR) - that "The right not to be discriminated against in the enjoyment of the rights guaranteed under the convention is also violated when states without an objective and reasonable justification fail to treat differently persons [i.e., unaccompanied migrant children] whose situations are significantly different." 165 In other words, a difference in treatment is only discriminatory when "it has no objective and reasonable justification."166

Therefore, distinctions in treatment able to match de facto vulnerable conditions of these children need to be introduced by state authorities in order to avoid violations to the protective mandate given by the American Convention. In fact, the introduction of differentiate treatments "constitute an instrument for the protection of those who should be protected, considering their situation of greater or lesser weakness or helplessness." ${ }^{167}$ E.g., unaccompanied migrant children. Among the different positive obligations that need to be developed within domestic legal systems, it would be possible to mention - for instance - the need to avoid the deprivation of liberty of unaccompanied children based on their migration status; the obligation to proactively search the whereabouts of the members of their families; the need to provide adequate legal assistance, access to education, health care, etc.

Based on the above considerations, together with a careful reading of the relevant conventional provisions under the light of the pro-persona and effet utile principles, it would be possible to conclude that the lack of introduction of additional safeguards for the protection of the rights of unaccompanied children would not only amount to a discriminatory treatment but also affect his or her right to life, survival and development. ${ }^{168}$ In fact, as recognized by the Committee on the Rights of the Child, the obligation to ensure, to the maximum extent possible, the survival and development of the child (as enshrined in Article 6 CRC) refers to "a holistic concept embracing the child's physical, mental, spiritual, moral, psychological and social development."169

162 Ibid.

163 See Rights and Guarantees of Children, supra note 7, para. 71. In fact, according to Bierwirth: "The principle of non-discrimination prohibits, for example, the different treatment of asylum-seeking children from differing countries of origin. All such children must be subject to the same general rules of procedure and must enjoy the same social rights. However, the principle of non-discrimination, if properly understood, does not prevent, but may in fact call for, a differentiation among refugee and asylum-seeking children on the basis of different protection needs deriving, for example, from their health status, age, trauma and/or persecution." (Bierwirth 2005, p. 102).

164 See Juridical Condition and Human Rights of the Child, supra note 51, para. 47.

165 Case of Thlimmenos v. Greece, Judgment of 6 April 2000, ECrtHR, No. 34369/97, para. 44.

166 Case of Willis $v$. The United Kingdom, Judgment 11 June 2002, ECrtHR, No. 36042/97, para. 39. See also-among others-Case of Wessels-Bergervoet v. The Netherlands, Judgment of 4 June 2002, ECrtHR, No. 34462/97, para. 46 and Case of Petrovic v. Austria, Judgment of 27 March 1998, ECrtHR, Reports 1998-II, para. 30.

167 Judicial Condition of Undocumented Migrants, supra note 159, para. 89.

168 See Rights and Guarantees of Children, supra note 7, para. 69 et. seq.

169 Committee on the Rights of the Child, General Comment No. 5, supra note 78, para. 12. 


\section{Conclusions}

This paper has critically analyzed how the Inter-American Court has enlarged the conventional protection of children's rights-and more specifically of migrant children-by means of implementing a systemic, evolutive, dynamic and effective interpretation of the American Convention under the light of human rights instruments that are part of the corpus juris of international human rights law.

In fact, the court has interpreted the convention under the light of all type of relevant norms and instruments (binding and non-binding) that integrate the corpus juris of international human rights law and even recognize the existence of the corpus juris for the protection of children. In particular, the regional tribunal has highlighted the interpretative importance of the provisions contained within the Convention on the Rights of the Child-as interpreted by the Committee on the Rights of the Child-for the determination of the extension and scope of protection of Article 19 ACHR.

The integration of the latter provision-under the light of the corpus juris for the protection of children's rights-has led to the development of concrete procedural and substantive safeguards based on the implementation of the principles of effective protection (effet utile) and the best interest of the child. Examples of these safeguards can be found in the recognition of the right of the child to be heard, in regard to all the aspects of legal proceedings that could directly affect him or her, and that his or her views are adequately taken into account. ${ }^{170}$ In other words, the specific situation of vulnerability that is inherently connected with the condition of being a minor demands from state authorities, higher levels of protection, including the obligation to determine, in the terms of Articles 19 ACHR, and in conformity with an evaluation of the best interest of the child, "the special measures of protection that are required to ensure their life, survival and development."171

Migrant children are not an exception to this hermeneutical rule. In their case, a differential procedural treatment is needed in order to guarantee equal access to the protection offered by the regional system, "based on the recognition that they do not participate in migratory proceedings under the same conditions as an adult." ${ }^{\prime 172}$ Among these guarantees, one can mention the obligation to provide the child with a translator; the right to participate in every stage of the proceedings; the right to effective access to legal assistance, including consular support; and the appointment of a guardian. ${ }^{173}$ Further, the court has recognized additional positive obligations that states should adopt in connection to unaccompanied children due to their specific situation of vulnerability. In this regard, for the regional tribunal, it would not be sufficient to provide adequate reception and accommodation facilities to unaccompanied child migrants in order to guarantee their effective protection, but also additional, concrete and specific efforts need to be allocated in order to-for instance-identify the whereabouts of his or her family members, among others. ${ }^{174}$

To conclude, the systemic, dynamic and evolutive integration of the American Convention, under the relevant provision of the corpus juris for the protection of the rights of the child, has paved the way for the development of higher levels of protection to migrant children's rights in the Americas. This integration has not only contributed to the further "harmonization of international law and principles" (Pasqualucci 2013, p. 13), but also-and even most importantly—to the affirmation of the imperative centrality of the protection and the superior interest of the human being under international law. ${ }^{175}$ The enhanced protection of the rights of migrant children is nothing but a reaffirmation of this gradual and constant process toward the 'humanization' of international law (Cançado Trindade 2013, p. 391 et seq).

170 Committee on the Rights of the Child, General Comment No. 12, supra note 124, para. 123.

171 Rights and Guarantees of Children, supra note 7, para. 103.

172 Ibid, para. 114.

173 See Section 4.

174 See Section 4.1 .

175 See Juridical Condition and Human Rights of the Child, supra note 41, Concurring Opinion of Judge Cançado Trindade, para. 18. 
Author Contributions: This article was designed and written by its two authors. A.F., Senior Researcher at the Raoul Wallenberg Institute (RWI), is the leading author of Section 1, Section 2, and Section 5; M.V., Doctoral Candidate at Umeå University, is the leading author of Sections 3 and 4.

Funding: This research received no external funding.

Conflicts of Interest: The authors declare no conflict of interest.

Disclaimer: The views and opinions expressed in this paper are exclusively those of the authors and do not necessarily reflect the official policy or position of the Raoul Wallenberg Institute of Human Rights and Humanitarian Law (RWI).

\section{Abbreviations}

ACHR
CRC
IACHR
IACrtHR
IHRL
UNHCR
VCLT

\section{References}

Aguilar Cavallo, Gonzalo. 2008. El principio del interés superior del niño y la Corte interamericana de derechos humanos. Estudios constitucionales 6: 223-47.

Arlettaz, Fernando. 2015. El caso Familia Pacheco Tineo: Expulsión de extranjeros, niñez migrante y asilo (Familia Pacheco Tineo case: Expulsion of foreigners, migrant childhood and asylum). Anuario de Derechos Humanos 11: 85-94.

Arlettaz, Fernando. 2016. Perspectiva interamericana sobre la afectación de la libertad de menores en procedimientos migratorios. Anuario Colombiano de Derecho Internacional (ACDI) 9: 197-231. [CrossRef]

Beduschi, Ana. 2015. The Contribution of the Inter-American Court of Human Rights to the Protection of Irregular Immigrants' Rights: Opportunities and Challenges. Refugee Survey Quarterly 34: 45-74. [CrossRef]

Beduschi, Ana. 2018. Vulnerability on Trial: Protection of Migrant Children's Rights in the Jurisprudence of International Human Rights. Boston University International Law Journal 36: 55-86.

Bierwirth, Christoph. 2005. The protection of refugee and asylum-seeking children, the convention on the Rights of the Child and the work of the Committee on the Rights of the Child. Refugee Survey Quarterly 24: 98-124. [CrossRef]

Cançado Trindade, Antônio Augusto. 2007. The Humanization of Consular Law: The Impact of Advisory Opinion No. 16 (1999) of the Inter-American Court of Human Rights on International Case-law and Practice. Chinese Journal of International Law 6: 1-16. [CrossRef]

Cançado Trindade, Antônio Augusto. 2013. International Law for Humankind: Towards a New Jus Gentinium, 2nd revised ed. Leiden: The Hague Academy of International Law, Martinus Nijhoff, vol. 8.

CGRS. 2015. Childhood and Migration in Central and North America: Causes, Policies, Practices and Challenges. San Francisco: CGRS.

Comune, Josefina, and Natalia Luterstein. 2012. Artículo 29. Normas de Interpretación. In La Convención Americana de Derechos Humanos y su proyección en el Derecho Argentino. Edited by Enrique Alonso Regueira. Buenos Aires: La Ley, pp. 519-33.

De Oliveira Mazzuoli, Valerio, and Dilton Ribeiro. 2016. The Pro Homine principle as an enshrined feature of International Human Rights Law. Indonesian Journal of International E Comparative Law 3: 77-99.

Dembour, Marie-Bénédicte. 2015. When Humans Become Migrants: Study of the European Court of Human Rights with an Inter-American Counterpoint. Oxford: University Press.

Feria Tinta, Mónica. 2007. Justiciability of Economic, Social, and Cultural Rights in the Inter-American System of Protection of Human Rights: Beyond Traditional Paradigms and Notions. Human Rights Quarterly 29: 431-59. [CrossRef]

Feria Tinta, Mónica. 2008. The Landmark Rulings of the Inter-American Court of Human Rights on the Rights of the Child: Protecting the Most Vulnerable at the Edge. Leiden: Martinus Nijhoff. 
Fuentes, Alejandro. 2016. Judicial Interpretation and Indigenous Peoples' Rights to Lands, Participation and Consultation. The Inter-American Court of Human Rights' Approach. International Journal on Minority and Group Rights 23: 39-79. [CrossRef]

Fuentes, Alejandro. 2018. Expanding the Boundaries of International Human Rights Law. The Systemic Approach of the Inter-American Court of Human Rights. European Society of International Law (ESIL) Conference Papers 10. [CrossRef]

Goldman, Robert K. 2009. History and Action: The Inter-American Human Rights System and the Role of the Inter-American Commission on Human Rights. Human Rights Quarterly 31: 856-87. [CrossRef]

Haeck, Yves, Osvaldo Ruiz Chiriboga, and Clara Burbano Herrera, eds. 2015. The Inter-American Court of Human Rights: Theory and Practice, Present and Future. Cambridge: Intersentia Publishers.

IACHR. 2008. The Rights of the Child in the Inter-American Human Rights System, 2nd ed. OEA/Ser. L/V/II. 133, Doc. 34. New York: IACHR.

IACHR. 2010. Report on Immigration in the United States: Detention and Due Process. OEA/Ser.I/V/II, Doc 78/10. New York: IACHR.

IACHR. 2011. Juvenile Justice and Human Rights in the Americas. OEA/Ser.L/V/II, Doc. 78. New York: IACHR.

IACHR. 2013a. Human Rights of Migrants and Other Persons in the Context of Human Mobility in Mexico. OEA/Ser. I./V/II, Doc 48/13. New York: IACHR.

IACHR. 2013b. The Right of Boys and Girls to a Family. OEA/Ser.L/V/II, Doc. 54/13 17. New York: IACHR.

IACHR. 2015a. Human Rights of Migrants, Refugees, Stateless Persons, Victims of Human Trafficking and Internally Displaced Persons: Norms and Standards of the Inter-American Human Rights System. OEA/ Ser. L/V/II, Doc. 46/15, 2015. New York: IACHR.

IACHR. 2015b. Refugees and Migrants in the United States: Families and Unaccompanied Children. OAS/Ser. L/V/II 155, Doc 16. New York: IACHR.

IACHR. 2017. Fulfillment of Children's Rights. OEA/Ser.L/V/II.166, Doc. 206/17. New York: IACHR.

Koskenniemi, M. 2006. Fragmentation of International Law: Difficulties Arising from the Diversification and Expansion of International Law, Report of the Study Group of the International Law Commission. A/cn.4/L.682. Geneva: International Law Commission, May 1-June 9 and July 3-August 11.

Lavrysen, Laurens. 2014. Positive Obligations in the Jurisprudence of the Inter-American Court of Human Rights. Inter-American and European Human Rights Journal 7: 94-115.

Lixinski, Lucas. 2010. Treaty Interpretation by the Inter-American Court of Human Rights: Expansionism at the Services of the Unity of International Law. The European Journal of International Law 21: 585-604. [CrossRef]

Lyon, Beth. 2004. The Inter-American Court of Human Rights Defines Unauthorized Migrant Workers' Rights for the Hemisphere: A Comment on Advisory Opinion 18. New York University Review of Law \& Social Change 28: 551-82.

Mason, Ashley. 2012. Interpretation of the American Convention in Latin America: The Impact of the Inter-American Court of Human Rights' Decision in Velez Loor v. Panama on Irregular Migrant Rights. Law and Business Review of the Americas 18: 71-82.

Mc Lachlan, Campbell. 2005. The Principle of Systemic Integration and Article 31 (3) (c) of the Vienna Convention. International and Comparative Law Quarterly 54: 279-319. [CrossRef]

Medina Quiroga, Cecilia. 2009. The Inter-American System for the Protection of Human Rights. In International Protection of Human Rights: A Textbook. Edited by Catarina Krause and Martin Scheinin. Turku: Åbo Akademi University Institute for Human Rights, pp. 475-501.

Miranda Bonilla, Haideer. 2015. Derechos fundamentales en América Latina. San José: Editorial Jurídica Continental.

Nola, Aoife, and Ursula Kilkelly. 2016. Children's Rights under Regional Human Rights Law, A Tale of Harmonization? In Towards Convergence in International Human Rights Law: Approaches of Regional and International Systems. Edited by Carla M. Buckley, Alice Donald and Philip Leach. Leiden: Brill Nijhoff, pp. 296-322.

Olmos Giupponi, Belen. 2017. Assessing the evolution of the Inter-American Court of Human Rights in the protection of migrants' rights: Past, present and future. The International Journal of Human Rights 21: 1477-503. [CrossRef]

Ortiz, Rosa Maria. 2015. Access to the Inter-American System: Standards and Challenges. In Child Friendly Justice. A Quarter of a Century of the UN Convention on the Rights of the Child. Edited by Said Mahmoudi, Pernilla Leviner, Anna Kaldal and Katrin Lainpelto. Leiden: Brill Nijhoff, pp. 335-39. 
Pasqualucci, Jo M. 2013. The Practice and Procedure of the Inter-American Court of Human Rights, 2nd ed. Cambridge: Cambridge University Press.

Pasqualucci, Jo M. 2014. Advisory Practice of the Inter-American Court of Human Rights: Contributing to the Evolution of International Human Rights Law. Stanford Journal of International Law 7: 241-88.

Rachovitsa, Adamantia. 2017. The principle of systemic integration in human rights law. International and Comparative Law Quarterly 66: 557-88. [CrossRef]

Tigroudja, Hélène. 2013. The Inter-American Court of Human Rights and international humanitarian law. In Research Handbook on Human Rights and Humanitarian Law. Edited by Robert Kolb and Gloria Gaggioli. Northampton: Edward Elgar Publishing.

UN High Commissioner for Refugees (UNHCR). 2014. Children on the Run: Unaccompanied Children Leaving Central America and Mexico and the need for International Protection; New York: UN High Commissioner for Refugees.

(C) 2019 by the authors. Licensee MDPI, Basel, Switzerland. This article is an open access article distributed under the terms and conditions of the Creative Commons Attribution (CC BY) license (http://creativecommons.org/licenses/by/4.0/). 